\title{
ZASTUPLJENOST DRUŠTVENIH NAUKA \\ U ŠKOLOVANJU OFICIRA, KOJE SU NEOPHODNE ZA POČETNE DUŽNOSTI
} U RADU SA LJUDIMA

\author{
Jasmina Milošević Stolić \\ Univerzitet odbrane u Beogradu, Vojna akademija
}

U ovom radu su izvršena komparativna istraživanja zastupljenosti društvenih nauka u okviru studijskih programa četiri visokoškolske vojne ustanove (Vojna akademija, Univerzitet odbrane u Beogradu, Univerzitet odbrane u Brnu, Češka Republika, Vojno učilište Republike Hrvatske, Vojna akademija "General Mihailo Apostolski“ - Skopje, Republika Severna Makedonija), značajnih za razvijanje kompetencija neophodnih za rad sa ljudima pri obavljanju početnih dužnosti profesionalnih vojnih lica. Pojam kompetencija neophodnih za rad sa ljudima definisan je kao kompleks znanja, veština i stavova neophodnih za obavljanje složenih funkcija i uloga oficira a koje se mogu klasifikovati kao sistemske i interpersonalne kompetencije. U skladu sa rezultatima komparacija, radi anticipacije novonastalih promena u sistemu odbrane, neophodno je realizovati kontinuirano i permanentno obrazovanje profesionalnih pripadnika vojske koje će biti usmereno ka daljem razvijanju kompetencija neophodnih za rad sa ljudima i obuku.

Ključne reči: kompetencije neophodne za rad sa ljudima, društvene nauke, vojno obrazovanje, oficirski kadar

\section{Uvod}

D ruštvene nauke, imaju cilj da analiziraju i interpretiraju vrednosti i interese u društvu, koji su usmereni kako na društvenu misao, tako i na društveno delovanje, odnosno praksu. Vrednost društvenih nauka, nalazi se upravo u razvijenoj refleksivnoj analizi vrednosti, pojava i procesa koja je suštinska za holistički razvoj društva. Značaj društvenih nauka u razvijanju kompetencija oficira, neophodnih za obavljanje njihovih početnih dužnosti je nesumnjiv. Ovde, pre svega, misli se na značaj znanja neophodnih za rad sa ljudima i realizaciju obuke, izgradnju međuljudskih odnosa, kao i razvijanje sposobnosti za uočavanje i analizu socioloških fenomena savremenog sveta, specifičnost rata i mira i vojnog poziva kroz vekove i posebno u eri globalizacije, kao i kompleksan i razvojan odnos i relaciju društva, države i vojske. Upravo ove nauke, omogućavaju shvatanje društvene suštine rata i mira i vojske kao društvene $i$ istorijske institucije u vremenu globalizacije i planetarnih promena i integracije današnjeg sveta. 


\section{Društvene nauke i njihov značaj za ojačavanje kompetenci- ja neophodnih u radu sa ljudima u vojnoj organizaciji}

Neophodnost posedovanja znanja utemeljenih u društvenim naukama, potvrdila su i istraživanja obrazovnih potreba profesionalnih vojnih lica. Ova istraživanja su, između ostalog, ukazala i na činjenicu da samo poznavanje vojne struke nije dovoljno za obavljanje poslova oficira koji se nalaze na početnim dužnostima, već su im neophodna didaktičko-metodička znanja i znanja potrebna za rad sa ljudima za realizaciju svojih profesionalnih dužnosti. Govoreći o strukturi znanja potrebnih za obavljanje ovih dužnosti veoma je značajno i posedovanje znanja koja se tiču poznavanja pravnih normi, koje regulišu pitanje odbrane i bezbednosti zemlje i osnovnih normi iz oblasti međunarodnog prava oružanih sukoba, kao i njenog položaja u celokupnom društvenom okruženju. Uspešno funkcionisanje vojske nemoguće je bez razmatranja zakonitosti ekonomskih procesa i karakteristika privrednog rasta i razvoja, u cilju izgradnje stabilnog i dinamičnog privrednog razvoja. Proširivanje, produbljivanje i sinteza znanja o politici i političkim sistemima, kao i kritičko razumevanje organizacije, funkcije i procesa političkog sistema i savremenih političkih sistema, doprineće razvijanju sposobnosti za kompetentnim praćenjem, razumevanjem i procenjivanjem aktuelnih i budućih političkih procesa i tendencija. Od savremenog oficira očekuje se da prepoznaje i uočava etičke probleme u vezi sa misijama vojske i vojnom profesijom i kritički o njima promišlja. Zato je neophodno da proučavajući istoriju i ratnu praksu u prošlosti, stekne određena iskustva i pouke koja će mu omogućiti funkcionalnije razumevanje savremene teorije ratne veštine, odnosno, njenih disciplina: taktike, operatike i strategije.

\section{Metodološki dizajn istraživanja}

Predmet istraživanja u ovom radu je zastupljenost društvenih nauka u funkciji osnaživanja kompetencija neophodnih za rad sa ljudima profesionalnih vojnih lica, tokom obavljanja početnih aktivnosti/uloga u studijskim programima osnovnih akademskih studija. U samom istraživanju pošlo se od pretpostavke koja ima uporište u opštim teorijskim saznanjima, kao i u rezultatima dosadašnjih empirijskih istraživanja, da postoje potrebe starešina za obrazovanjem iz oblasti društvenih nauka, koje je u funkciji kompetencijskog osnaživanja njihovih znanja neophodnih za rad sa ljudima pri obavljanju početnih starešinskih dužnosti.

Izbor osnovne istraživačke paradigme bio je uslovljen prirodom predmeta i opštim ciljem istraživanja, pa je stoga i odabran teorijsko-empirijski pristup s akcentom na analizi, sintezi i generalizaciji kvantitativnih podataka. Primenjena je komparativna metoda radi utvrđivanja zastupljenost društvenih nauka u studijskim programima visokoškolskih vojnih ustanova (Vojna akademija, Univerzitet odbrane u Beogradu, Univerzitet odbrane u Brnu, Republika Češka, Vojno učilište Republike Hrvatske, Vojna akademija „General Mihailo Apostolski“ - Skopje, Republika Severna Makedonija), u cilju razvijanja kompetencija neophodnih za rad sa ljudima na njihovim početnim dužnostima, u sistemu vojnog formalnog obrazovanja. 
Navedeni opšti cilj ostvaren je preko sledećih posebnih ciljeva istraživanja:

1. Utvrditi zastupljenost nastavnih predmeta društvenih nauka u studijskim programima Vojne akademije Univerziteta odbrane u Beogradu usmerenih na razvijanje kompetencija neophodnih za rad sa ljudima na njihovim početnim dužnostima;

2. Utvrditi zastupljenost nastavnih predmeta društvenih nauka u studijskim programima Univerziteta odbrane u Češkoj Republici usmerenih, na razvijanje kompetencija neophodnih za rad sa ljudima na njihovim početnim dužnostima;

3. Utvrditi zastupljenost nastavnih predmeta društvenih nauka u studijskim programima Vojnog učilišta u Hrvatskoj usmerenih, na razvijanje kompetencija neophodnih za rad sa ljudima na njihovim početnim dužnostima;

4. Utvrditi zastupljenost nastavnih predmeta društvenih nauka u studijskim programima Voene akedemije „General Mihailo Apostolski“ Severne Makedonije, usmerenih, na razvijanje kompetencija neophodnih za rad sa ljudima na njihovim početnim dužnostima;

5. Ispitati i utvrditi sličnosti i razlike u odnosu na predmete društvenih nauka studijskih programa univerziteta odbrane Republike Srbije i Republike Češke i vojnih akademija Republike Hrvatske i Republike Severne Makedonije u pogledu (stvaranja uslova) usmerenih, na razvijanje kompetencija neophodnih za rad sa ljudima na njihovim početnim dužnostima koristeći sledeće indikatore komparacije: naziv predmeta, broj časova i broj ESPB bodova.

Komparativna istraživanja zastupljenosti predmeta društvenih nauka, studijskih programa Univerziteta odbrane Republike Srbije i Republike Češke i vojnih akademija Republike Hrvatske i Republike Severne Makedonije, u pogledu razvijanja kompetencija, neophodnih za rad sa ljudima, koje se prevashodno razvijaju kroz sadržaje ovih nauka ograničeni su na nivo osnovnih studija, zbog preobimnosti rada. U ovom radu su korišćeni sledeći indikatori komparacije: naziv predmeta, broj časova i broj ESPB bodova.

Kompetencije neophodne za rad sa ljudima, definisane su kao skup znanja i veština potrebnih pojedincu za obavljanje početnih oficirskih funkcija i uloga. Osim toga, kompetencije neophodne za rad sa ljudima (znanja i veštine) oficira diferencirani su na interpersonalne i sistemske. Interpersonalne kompetencije odnose se na stručna znanja i veštine neophodne za neposredni rad sa ljudima, dok sistemske obuhvataju širi spektar znanja i veština neophodnih za razumevanje složenih odnosa pojedinca, vojne organizacije i društva u celini.

\section{Analiza i interpretacija rezultata istraživanja}

\section{Zastupljenost društvenih nauka u studijskim programima obrazovnih visokoškolskih vojnih ustanova u funkciji osnaživanja njihovih kompetencija neophodnih za rad sa ljudima}

Pored niza obaveznih i izbornih predmeta, usmerenih ka usvajanju znanja i veština potrebnih za obavljanje uskostručnih oficirskih dužnosti, struktura osnovnih akademskih studija proučavanih univerziteta i akademija obuhvata i one oblasti koje su neophodne za ovladavanje znanjima i veštinama koje se odnose na poznavanje ljudi, brige o njima, formiranje kvalitetnih međuljudskih odnosa, i izgrađivanje motivacije u ovoj specifičnoj društvenoj organizaciji. 
Univerzitet odbrane u Beogradu čine Vojna akademija i Medicinski fakultet Vojnomedicinske akademije. U okviru Vojne akademije realizuju se sledeći studijski programi: Menadžment u odbrani, Vojnomašinsko inženjerstvo, Vojnohemijsko inženjerstvo, Atomskobiološko-hemijske odbrane, Protivvazduhoplovna odbrana, Javne finansije, Logistika, Vojnogeodetsko inženjerstvo i Vojno vazduhoplovstvo-integrisane studije. U okviru Medicinskog fakulteta Vojnomedicinske akademije realizuje se studijski program integrisanih akademskih studija "Doktor medicine“.

U okviru Vojne akademije Univerziteta odbrane u Beogradu, na osnovnim akademskim studijama kadeti slušaju sledeće obavezne i izborne predmete društvenih nauka usmerene ka razvijanju kompetencija, neophodnih za rad sa ljudima, u toku obavljanja njihovih profesionalnih dužnosti: Pravo odbrane i međunarodno humanitarno pravo, Sociologija, Osnovi ekonomije, Vojna istorija, Vojna psihologija, Menadžment ljudskih resursa, Vojna andragogija, Komandovanje i rukovođenje, Finansijski menadžment, Osnovi menadžmenta, Osnovi organizacije, Komunikacije s javnošću, Politički sistem, Bioterorizam, Krizni menadžment, Vojna etika, Uvod u strategiju i operatiku i Vojna logistika (tabela 1).

Navedeni predmeti analizirani su u odnosu na sledeće indikatore: naziv predmeta, broj časova aktivne nastave, broj ESPB bodova, kao i status predmeta (obavezan ili izborni).

Tabela 1 - Društveni predmeti u studijskim programima osnovnih akademskih studija Vojne akademije Univerziteta odbrane u Beogradu

\begin{tabular}{|c|c|c|c|c|c|}
\hline \multicolumn{6}{|c|}{$\begin{array}{l}\text { Vojna akademija u Beogradu } \\
\text { OSNOVNE AKADEMSKE STUDIJE }\end{array}$} \\
\hline & \multicolumn{5}{|c|}{ Obavezni predmeti } \\
\hline & Predmet & Sem & $\mathrm{P}$ & V & ESPB \\
\hline 1. & Pravo odbrane i međunarodno humanitarno pravo & 1 & 2 & 1 & 4 \\
\hline 2. & Sociologija & 1 & 2 & 1 & 3 \\
\hline 3. & Osnovi ekonomije & 2 & 3 & 1 & 4 \\
\hline 4. & Vojna istorija & 2 & 2 & 2 & 4 \\
\hline 5. & Vojna psihologija & 3 & 2 & 1 & 3 \\
\hline 6. & Menadžment ljudskih resursa & 3 & 3 & 1 & 3 \\
\hline 7. & Vojna andragogija & 4 & 2 & 1 & 3 \\
\hline 8. & Komandovanje i rukovođenje & 4 & 3 & 1 & 5 \\
\hline 9. & Finansijski menadžment & 7 & 3 & 1 & 3 \\
\hline
\end{tabular}

\begin{tabular}{|c|l|c|c|c|c|}
\hline & \multicolumn{4}{|c|}{ Izborni predmeti } \\
\hline 1. & Osnovi menadžmenta & 1 & 2 & 1 & 3 \\
\hline 2. & Osnovi organizacije & 1 & 2 & 1 & 3 \\
\hline 3. & Komunikacije s javnošću & 3 & 2 & 1 & 3 \\
\hline 4. & Politički sistem & 3 & 2 & 1 & 3 \\
\hline 5. & Bioterorizam & 3 & 2 & 1 & 3 \\
\hline 6. & Krizni menadžment & 6 & 3 & 1 & 4 \\
\hline 7. & Vojna etika & 8 & 3 & - & 3 \\
\hline 8. & Uvod u strategiju i operatiku & 8 & 3 & 1 & 3 \\
\hline 9. & Vojna logistika & 8 & 2 & 1 & 3 \\
\hline
\end{tabular}


Univerzitet odbrane Republike Češke čine Fakultet za vojni menadžment, Fakultet Vojnih tehnologija i Fakultet vojnog zdravstva. Fakultet vojnog menadžmenta ima razvijeni studijski program „Ekonomija i menadžment“. Fakultet vojnih tehnologija u svojoj strukturi ima razvijen program „Vojne tehnologije," Fakultet vojnog zdravstva realizuje studijski program „Vojnomedicinskog upravljanja“.

Fakultet vojnog menadžmenta Univerziteta odbrane u Brnu (Republika Češka) je garant studijskog programa „Ekonomija i menadžment“. U okviru ovog studijskog programa razvijeno je studijsko područje „Vojni menadžment“. Kadeti ovog studijskog područja ovladavaju znanjima iz 11 obaveznih predmeta: Ekonomika 1 - Mikroekonomija; Menadžment 1, Osnove prava i međunarodnog humanitarnog prava, Ekonomika 1 - Makroekonomika, Istorija i tradicije Armije Češke Republike, Socijalni i psihološki aspekt Menadžmenta, Vojni menadžment 1, Ekonomika i Logistika Armije, Javna Ekonomija, Ekonomska teorija: Istorija i Administrativno pravo i pravo bezbednosti i odbrane (tabela 2).

Tabela 2 - Društveni predmeti obaveznog karaktera u studijskom području „Vojni menadžment“ osnovnih akademskih studija Fakulteta vojnog rukovođenja Univerziteta odbrane u Brnu, Republika Češka

\begin{tabular}{|c|c|c|c|c|c|c|c|c|c|c|}
\hline & Predmet & $S$ & PV & $\begin{array}{l}E S \\
P B\end{array}$ & $S$ & PV & $\begin{array}{l}E S \\
P B\end{array}$ & $S$ & PV & $\begin{array}{l}E S \\
P B\end{array}$ \\
\hline & \multicolumn{10}{|c|}{ Obavezni predmeti } \\
\hline 1. & Ekonomika 1 - Mikroekonomija & 1 & 52 & 5 & 2 & 52 & 5 & & & \\
\hline 2. & Menadžment 1 & 1 & 78 & 5 & 2 & 78 & 5 & & & \\
\hline 3. & $\begin{array}{l}\text { Osnove prava i međunarodnog } \\
\text { humanitarnog prava }\end{array}$ & 1 & 26 & 4 & 2 & 26 & 4 & & & \\
\hline 4. & Ekonomika 1 - Makroekonomika & 1 & 52 & 5 & 3 & 52 & 5 & & & \\
\hline 5. & $\begin{array}{l}\text { Istorija i tradicije Armije Češke } \\
\text { Republike }\end{array}$ & 1 & 26 & 2 & 3 & 26 & 2 & & & \\
\hline 6. & $\begin{array}{l}\text { Socijalni i psihološki aspekt } \\
\text { Menadžmenta }\end{array}$ & 1 & 26 & 1 & 3 & 26 & 1 & & & \\
\hline 7. & Vojni menadžment 1 & 1 & 52 & 4 & 4 & 39 & 3 & 5 & 13 & 1 \\
\hline 8. & Ekonimika i Logistika Armije & 1 & 26 & 2 & 5 & 26 & 2 & & & \\
\hline 9. & Javna Ekonomija & 1 & 78 & 6 & 3 & 26 & 2 & 4 & 52 & 4 \\
\hline 10. & Ekonomska teorija: Istorija & 1 & 26 & 2 & 4 & 26 & 2 & & & \\
\hline 11. & $\begin{array}{l}\text { Administrativno pravo i pravo } \\
\text { bezbednosti i odbrane }\end{array}$ & 1 & 26 & 2 & 5 & 26 & 2 & & & \\
\hline
\end{tabular}

Kada je reč o izbornim predmetima, od 178 predmeta ove grupe, izdvojeno je 40 predmeta koji pretežno pripadaju ekonomskim i političkim naukama. U ovu grupu predmeta svrstani su sledeći izborni predmeti iz menadžerskog i vojnog područja: Uvod u teoriju bezbednosti, Sociologija, Vojna etika I, Vojna etika II, Vojna ekonomija, Akademsko pisanje, Kognitivni menadžment, Krizni menadžment, Logistička podrška, Retorika komandanta vojne jedinice i komunikaciona obuka, Vojno rukovođenje, Etika vojnih profesionalaca, Vojna veština, i oružane snage, Kognitivni menadžment, Menadžerska komunikacija, Međunarodno pravo u aktivnostima Republike Češke (tabela 3 i tabela 4). 
Tabela 3 - Društveni predmeti izbornog karaktera u studijskom području „Vojni menadžment" osnovnih akademskih studija Fakulteta vojnog rukovođenja Univerziteta odbrane u Brnu, Republika Češka

\begin{tabular}{|c|c|c|c|c|c|c|c|c|c|c|c|c|c|}
\hline & Predmeti izbornog bloka 1 & S & PV & $\begin{array}{l}E S \\
P B\end{array}$ & $S$ & PV & \begin{tabular}{|l|}
$E S$ \\
$P B$
\end{tabular} & S & PV & $\begin{array}{l}E S \\
P B\end{array}$ & $S$ & PV & \begin{tabular}{|l|}
$E S$ \\
$P B$
\end{tabular} \\
\hline 1. & $\begin{array}{l}\text { Aktuelni događaji socijalnog i ekonom- } \\
\text { skog razvoja Republike Češke }\end{array}$ & 1 & 24 & 2 & 2 & 24 & 2 & & & & & & \\
\hline 2. & $\begin{array}{l}\text { Metode kreativnog rada } \\
\text { u ekonomiji }\end{array}$ & 1 & 24 & 2 & 2 & 24 & 2 & & & & & & \\
\hline 3. & Mikroekonomika & 1 & 24 & 2 & 2 & 24 & 2 & & & & & & \\
\hline 4. & Politika & 1 & 24 & 2 & 2 & 24 & 2 & & & & & & \\
\hline 5. & Uvod u teoriju bezbednosti & 1 & 24 & 2 & 2 & 24 & 2 & & & & & & \\
\hline 6. & Fundamenti zaštite populacije & 1 & 24 & 2 & 2 & 24 & 2 & & & & & & \\
\hline 7. & $\begin{array}{l}\text { Penzioni sistem i socijalna politika } \\
\text { u Češkoj Republici }\end{array}$ & 1 & 24 & 2 & 3 & 24 & 2 & & & & & & \\
\hline 8. & Vojna etika I & 1 & 24 & 2 & 3 & 24 & 2 & & & & & & \\
\hline 9. & Pitanja Vojne ekonomije & 1 & 24 & 2 & 3 & 24 & 2 & & & & & & \\
\hline 10. & Fondacije ekonomske analize & 1 & 24 & 2 & 3 & 24 & 2 & & & & & & \\
\hline 11. & Ekonomija životne sredine & 1 & 48 & 4 & 4 & 24 & 2 & 5 & 24 & 2 & & & \\
\hline 12. & $\begin{array}{l}\text { Retorika komandanta vojne } \\
\text { jedinice i komunikaciona obuka }\end{array}$ & 1 & 78 & 6 & 4 & 26 & 2 & 5 & 26 & 2 & 6 & 26 & 2 \\
\hline 13. & Vojna etika II & 1 & 48 & 4 & 4 & 24 & 2 & 6 & 24 & 2 & & & \\
\hline 14. & $\begin{array}{l}\text { Odabrani događaji Istorije ekonomske } \\
\text { teorije: Češka ekonomija }\end{array}$ & 1 & 24 & 2 & 4 & 24 & 2 & & & & & & \\
\hline 15. & Akademsko pisanje & 1 & 24 & 2 & 5 & 24 & 2 & & & & & & \\
\hline 16. & $\begin{array}{l}\text { Aktuelni događaji svetske } \\
\text { ekonomije }\end{array}$ & 1 & 0 & 2 & 5 & 0 & 2 & & & & & & \\
\hline 17. & Ekonomske odluke & 1 & 24 & 2 & 5 & 24 & 2 & & & & & & \\
\hline 18. & Ekonomija: krizne situacije & 1 & 24 & 2 & 5 & 24 & 2 & & & & & & \\
\hline 19. & Marketinška komunikacija & 1 & 24 & 2 & 5 & 24 & 2 & & & & & & \\
\hline 20. & $\begin{array}{l}\text { Javi sektor Ekonomije: odabrani } \\
\text { događaji }\end{array}$ & 1 & 24 & 2 & 5 & 24 & 2 & & & & & & \\
\hline 21. & Engleska ekonomska terminologija & 1 & 24 & 2 & 6 & 24 & 2 & & & & & & \\
\hline 22. & Kognitivni menadžment & 1 & 30 & 2 & 6 & 30 & 2 & & & & & & \\
\hline 23. & Marketing u oblasti transporta & 1 & 24 & 2 & 6 & 24 & 2 & & & & & & \\
\hline 24. & $\begin{array}{l}\text { Administrativni zakoni i delovi } \\
\text { administrativnih zakona }\end{array}$ & 1 & 24 & 2 & 6 & 24 & 2 & & & & & & \\
\hline 25. & $\begin{array}{l}\text { Javna ekonomija - odabrana } \\
\text { poglavlja }\end{array}$ & 1 & 24 & 2 & 6 & 24 & 2 & & & & & & \\
\hline 26. & $\begin{array}{l}\text { Krizni menadžment u inžinjerijskoj } \\
\text { podršci }\end{array}$ & 1 & 26 & 2 & 7 & 26 & 2 & & & & & & \\
\hline 27. & $\begin{array}{l}\text { Personalni rad u multikulturalnim } \\
\text { kompanijama }\end{array}$ & 1 & 24 & 2 & 7 & 24 & 2 & & & & & & \\
\hline 28. & $\begin{array}{l}\text { Planski i izveštajni dokumenti } \\
\text { logističkih jedinica }\end{array}$ & 1 & 26 & 0 & 7 & 26 & 0 & & & & & & \\
\hline 29. & $\begin{array}{l}\text { Liberalni zakoni i zakoni socijalne } \\
\text { bezbednosti }\end{array}$ & 1 & 24 & 2 & 7 & 24 & 2 & & & & & & \\
\hline 30. & Sociologija & 1 & 24 & 2 & 7 & 24 & 2 & & & & & & \\
\hline 31. & $\begin{array}{l}\text { Osnovni pravci razvoja } \\
\text { Menadžmenta u 21. veku }\end{array}$ & 1 & 24 & 2 & 7 & 24 & 2 & & & & & & \\
\hline 32. & Odabrani problemi Mikroekonomije & 1 & 26 & 2 & 7 & 26 & 2 & & & & & & \\
\hline 33. & $\begin{array}{l}\text { Logistička podrška: nezavisne } \\
\text { jedinice }\end{array}$ & 1 & 24 & 2 & 5 & 24 & 2 & & & & & & \\
\hline
\end{tabular}


Tabela 4 - Društveni predmeti izbornog karaktera u studijskom području „Vojni menadžment“ osnovnih akademskih studija Fakulteta vojnog rukovođenja Univerziteta odbrane u Brnu, Republika Češka

\begin{tabular}{|c|l|c|c|c|c|c|c|}
\cline { 2 - 8 } \multicolumn{1}{l|}{} & Predmeti izbornog bloka 2 & S & PV & ESPB & S & PV & ESPB \\
\hline 34. & Etika vojnih profesionalaca & 1 & 26 & 2 & 2 & 26 & 2 \\
\hline 35. & Vojna veština & 1 & 26 & 2 & 2 & 26 & 2 \\
\hline 36. & Bezbednost i oružane snage & 1 & 26 & 2 & 3 & 26 & 2 \\
\hline 37. & Kognitivni menadžment & 1 & 30 & 2 & 4 & 30 & 2 \\
\hline 38. & Menadžerska komunikacija & 1 & 26 & 2 & 4 & 26 & 2 \\
\hline 39. & $\begin{array}{l}\text { Međunarodno pravo u aktivnostima } \\
\text { Republike Češke }\end{array}$ & 1 & 24 & 4 & 5 & 24 & 4 \\
\hline 40. & Vojno rukovođenje & 1 & 52 & 4 & 6 & 26 & 2 \\
\hline
\end{tabular}

Sveučilište u Zagrebu za potrebe Oružanih snaga $\mathrm{RH}(\mathrm{OSRH})$ razvilo je sledeće studijske programe: 1) Sveučilišni diplomski studij „Vojno inženjerstvo“ i 2) Sveučilišni diplomski studij „Vojno vođenje i upravljanje“. Ovi studijski programi su namenjeni za obrazovanje budućih pripadnika OS RH. Razvijeni su u saradnji OS RH i Sveučilišta u Zagrebu. Školovanje kadeta na fakultetima odvija se prema istom programu, kao i za ostale polaznike visokoškolskih institucija, uz dodatak programa vojne obuke, kao dela programa koji će izučavati u vojnim kampovima, kao i kroz nastavne module za OS RH. ${ }^{1}$ Vojna obuka se pretežno izučava u Hrvatskom vojnom učilištu „Dr. Franjo Tuđman.“

U okviru studijskih programa Sveučilišta u Zagrebu - vojne studije, na osnovnim akademskim studijama, kadeti slušaju sledeće obavezne predmete društvenih nauka usmerene ka razvijanju kompetencija, neophodnih za rad sa ljudima, u toku obavljanja njihovih profesionalnih dužnosti: Međunarodno pravo-odabrana poglavlja, Vojna istorija, Akademsko pisanje i metode istraživanja, Država i ustav, Vojno upravljanje, Savremene civilizacije, Vojna pedagogija, Vojna psihologija, Ekonomija odbrane, Mediji propaganda i odnosi s javnošću, Sociologija vojske i rata, Etika vojnog poziva, Javna uprava i Međunarodna i EU sigurnost (tabela 5).

Tabela 5 - Društveni predmeti u studijskom programu osnovnih akademskih studija Sveučilišta u Zagrebu - vojne studije, Republika Hrvatska

\begin{tabular}{|c|c|c|c|c|c|c|}
\hline \multicolumn{7}{|c|}{$\begin{array}{l}\text { Sveučilište u Zagrebu, Vojne studije } \\
\text { OSNOVNE AKADEMSKE STUDIJE }\end{array}$} \\
\hline & Predmet & Sem & $P$ & V & S & ESPB \\
\hline 1. & Međunarodno pravo odabrana poglavlja & 1 & 2 & & 2 & 5 \\
\hline 2. & Vojna istorija & 1 & 2 & & 2 & 5 \\
\hline 3. & Akademsko pisanje i metode istraživanja & 1 & 2 & & 2 & 4 \\
\hline 4. & Država i ustav & 1 & 2 & & 2 & 4 \\
\hline 5. & Vojno vođenje & 3 & 3 & & 1 & 5 \\
\hline 6. & Savremene civilizacije & 3 & 2 & & 1 & 3 \\
\hline 7. & Vojna pedagogija & 4 & 2 & 1 & 1 & 4 \\
\hline 8. & Vojna psihologija & 4 & 2 & 2 & & 4 \\
\hline 9. & Ekonomija odbrane & 4 & 2 & 1 & 1 & 4 \\
\hline 10. & Mediji propaganda i odnosi s javnošću & 4 & 2 & 1 & 1 & 4 \\
\hline 11. & Sociologija vojske i rata & 4 & 2 & & 1 & 5 \\
\hline 12. & Etika vojnog poziva & 6 & 2 & & 1 & 3 \\
\hline 13. & Javna uprava & 6 & 2 & & 2 & 4 \\
\hline 14. & Međunarodna i EU sigurnost & 7 & 2 & & 2 & 5 \\
\hline
\end{tabular}

\footnotetext{
${ }^{1}$ Osim toga, kadeti-vojni piloti su stipendisti OS RH koji svoja prava i obaveze ostvaruju ugovorom o školovanju
} odnosno stipendiranju na preddiplomskom studiju aeronautike na Fakultetu prometnih znanosti (vojni@unizg.hr). 
Vojna akademija u Skoplju, Republika Severna Makedonija, u svojoj strukturi ima sledeće studijske programe: Upravljanje resursima, Telekomunikacije u obrazovno zaštitnom sistemu, Nuklearno-hemijsko-biološku zaštitu i Kontrolu vazdušnog prostora.

U okviru studijskih programa Vojne akademije u Skoplju, na osnovnim akademskim studijama, kadeti slušaju sledeće obavezne i izborne predmete društvenih nauka, usmerene ka razvijanju kompetencija, neophodnih za rad sa ljudima, u toku obavljanja njihovih profesionalnih dužnosti: Međunarodno vojno i humanitarno pravo, Upravno pravo, Komunikacija i komunikacijske veštine, Vojna istorija, Vojna andragogija, Vojna psihologija, Krizni menadžment, Ustavno pravo i politički sistem, Organizacija i menadžment, Rukovođenje i liderstvo i Sociologiju (tabela 6).

Tabela 6 - Društveni predmeti u studijskom programu osnovnih akademskih studija Vojne akademije u Skoplju, Republika Severna Makedonija

\begin{tabular}{|c|c|c|c|c|c|}
\hline \multicolumn{6}{|c|}{$\begin{array}{l}\text { Vojna akademija u Makedoniji } \\
\text { OSNOVNE AKADEMSKE STUDIJE }\end{array}$} \\
\hline & Obavezni predmeti & Semestar & $P$ & V & ESPB \\
\hline 1. & Međunarodno vojno i humanitarno pravo & 1 & 2 & 2 & 5 \\
\hline 2. & Upravno pravo & 1 & 2 & 1 & 4 \\
\hline 3. & Komunikacija i komunikacijske veštine & 3 & 2 & 1 & 4 \\
\hline 4. & Vojna istorija & 4 & 2 & 1 & 4 \\
\hline 5. & Vojna andragogija & 4 & 2 & 1 & 4 \\
\hline 6. & Vojna psihologija & 4 & 2 & 1 & 4 \\
\hline \multirow[t]{2}{*}{7.} & Krizni menadžment & 4 & 2 & 1 & 4 \\
\hline & Izborni predmeti & Semestar & $P$ & V & ESPB \\
\hline 1. & Ustavno pravo i politički sistem & 1 & 2 & 1 & 4 \\
\hline 2. & Organizacija i menadžment & 2 & 2 & 1 & 5 \\
\hline 3. & Rukovođenje i liderstvo & 2 & 2 & 1 & 5 \\
\hline 4. & Sociologija & 3 & 2 & 1 & 4 \\
\hline
\end{tabular}

Komparacija studijskih programa Univerziteta odbrane Republike Srbije i Republike Češke, Sveučilišta u Republici Hrvatskoj i Vojne akademije u Severnoj Makedoniji, ukazuje na činjenicu da se u okviru proučavanih visokoškolskih ustanova, na osnovnom nivou studija, izučavaju predmeti usmereni ka razvoju sistemskih i interpersonalnih kompetencija, neophodnih za rad sa ljudima. Teorijsko - komparativni pristup ukazao je i na postojanje razlika u odnosu na predmete usmerene ka formiranju proučavanih kompetencija u okviru posmatranih visokoškolskih ustanova (tabela 7). 
Tabela 7 - Uporedna tabela društvenih predmeta Osnovnih akademskih studija Univerzitet odbrane u Beogradu, Univerzitet odbrane, Brno, Češka Republika, Vojne akademije iz Zagreba, Republike Hrvatske, Vojna akademija "General Mihailo Apostolski“ - Skopje, Republika Severna Makedonija

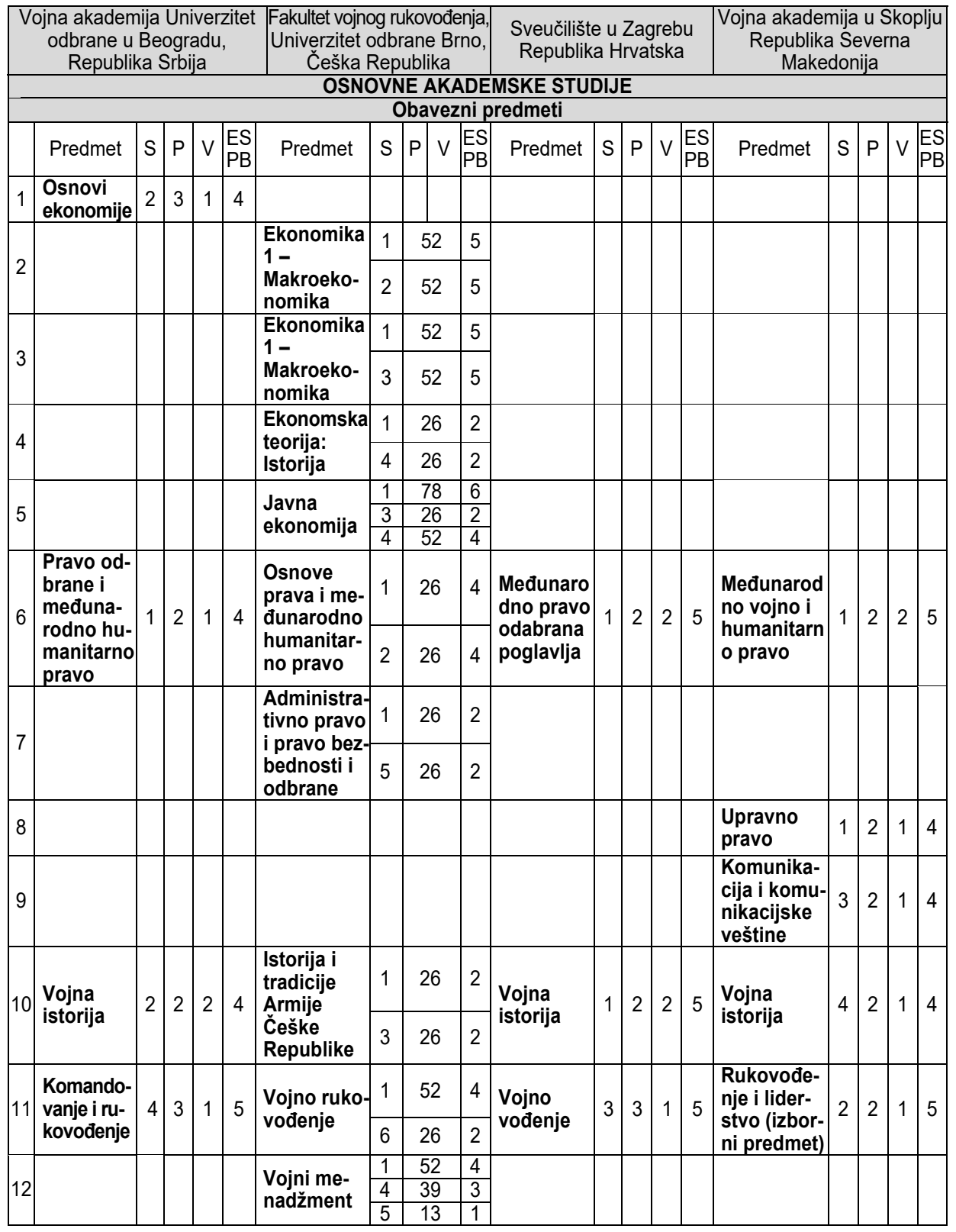


Sistem odbrane

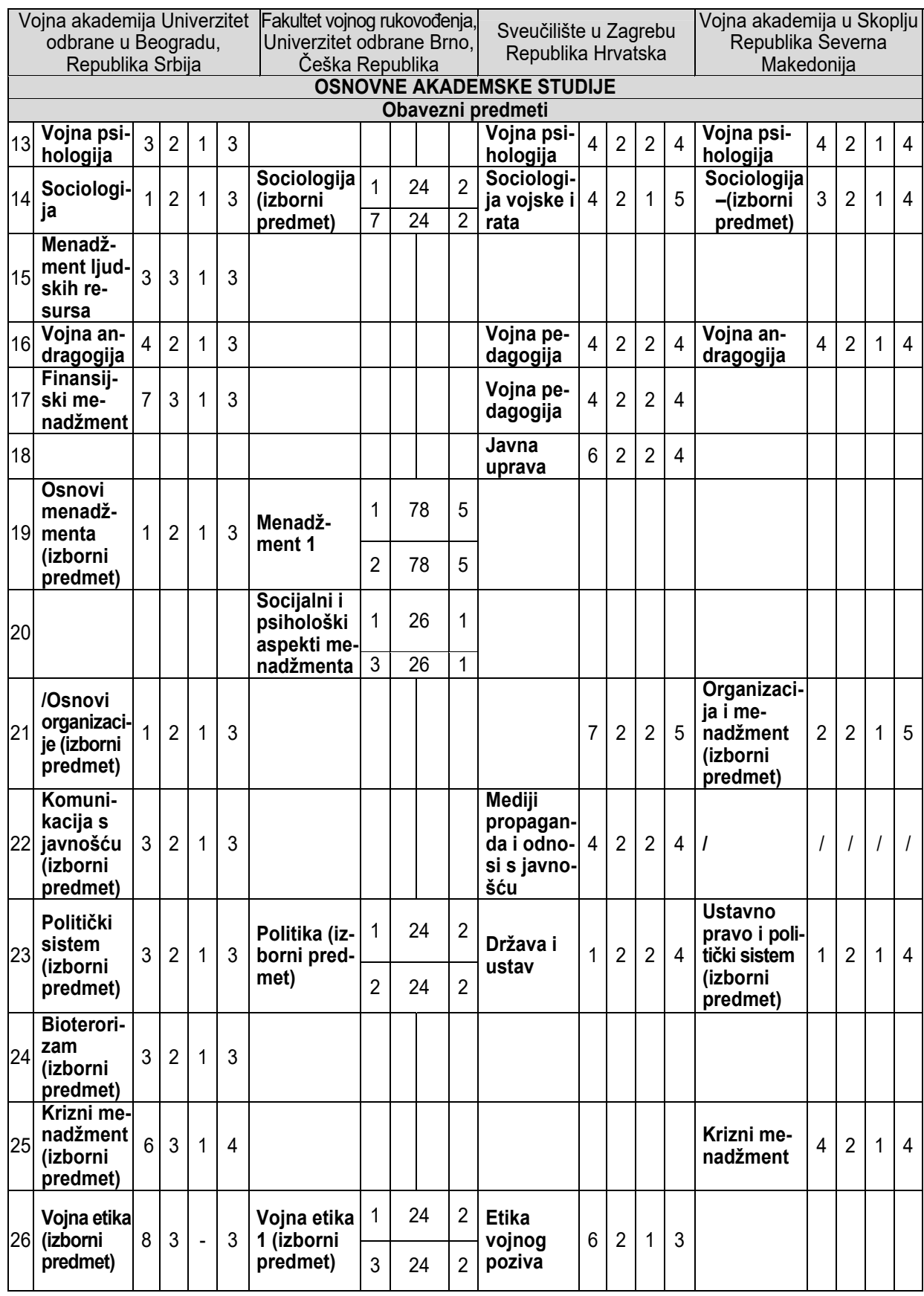




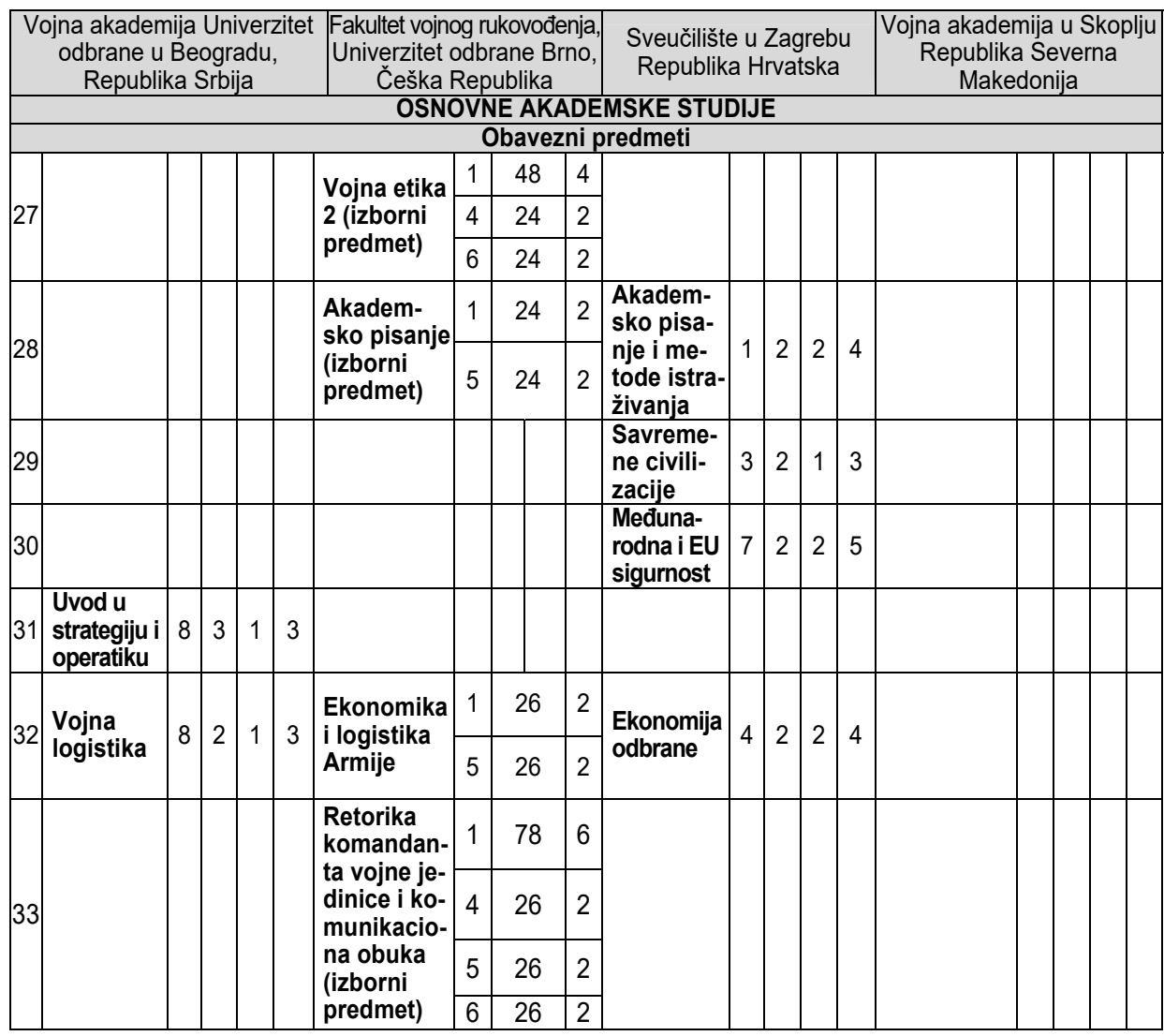

U odnosu na predmete usmerene ka razvijanju lingvističkih kompetencija koje se odnose na formiranje sposobnosti usmene i pisane komunikacije na maternjem jeziku, kao i izgradnji stavova usmerenih ka razvijanju osetljivosti za kulturne razlike i otporu prema stereotipima, najrazvijenije predmete ove oblasti imaju studijski programi Univerziteta odbrane Češke.

$\mathrm{U}$ odnosu na predmete usmerene ka razvijanju sistemskih kompetencija, neophodnih za razumevanje pravnih normi koje regulišu pitanje odbrane i bezbednosti zemlje a koji se realizuju kroz predmete pravnih nauka, najrazvijenije programe imaju studije Republike Češke i Republike Severne Makedonije. Predmeti usmereni ka proučavanju socioloških aspekata vojne organizacije, kao osnove za proučavanje kompetencija neophodnih za rad sa ljudima, najrazvijeniji su u studijskim programima Republike Češke i Republike Hrvatske, dok su najmanje zastupljeni u studijama Republike Severne Makedonije. U odnosu na predmete usmerene ka formiranju sistemskih kompetencija neophodnih za razumevanje i delovanje u, okviru sistema finansiranja i ekonomije gotovo podjednako razvijene programe imaju univerziteti u Beogradu, Ceškoj, Hrvatskoj, dok Vojna akademija Republike Severne Makedonije, nema razvijen ni jedan predmet ove oblasti, što nam se čini neopravdano s obzirom na potrebe profila kadrova koje školuju. 
U odnosu na predmete usmerene ka formiranju sistemskih kompetencija, svrstavaju se i predmeti usmereni ka proučavanju istorijskih aspekata razvoja oružane sile, vojne organizacije i ratne veštine u cilju sagledavanja uzroka, ciljeva, karaktera i posledica proteklih ratova, kao neophodnih za razumevanje savremenih ratova u funkciji obrazovnovaspitne komponente i moralno-psihološke podrške oficirima u savremeno doba. Navedeni sadržaji inkorporirani u korpus istorijskih nauka, podjednako su zastupljeniji u studijskim programima proučavanih univerziteta.

Predmet usmeren ka razvijanju sistemskih kompetencija, neophodnih u radu sa ljudima, u smislu njihovog osposobljavanja za kritičko razumevanje organizacije, funkcije i procesa savremenih političkih sistema i razvijanje sposobnosti za kompetentnim praćenjem, razumevanjem i procenjivanjem aktuelnih i budućih političkih procesa i tendencija, razvijeniji je u okviru Univerziteta odbrane u Beogradu i Univerziteta odbrane u Republici Češkoj, nego u visokoškolskim vojnim ustanova u Republici Hrvatskoj i Republici Severnoj Makedoniji.

Analize planova studija jasno nam govore da se u odnosu na proučavane kompetencije izdvajaju dve grupe srodnih programa u okviru različitih univerziteta. Tako vidimo da su u odnosu na ove kompetencije, Fakultet za vojno rukovođenje Univerziteta odbrane Češke Republike, studijski program Menadžment u odbrani Univerziteta odbrane u Beogradu, veoma kompatibilni, kao i da su u okviru ovih programa veoma razvijeni predmeti usmereni ka razvoju kompetencija neophodnih za rad sa ljudima.

\section{Zaključak}

Zaključujemo da u odnosu na postavljeni opšti cilj, odnosno posebne ciljeve istraživanja koji su se odnosili na utvrđivanje sličnosti i razlika studijskih programa univerziteta Srbije, Češke, Hrvatske i Severne Makedonije i, u pogledu razvijanja kompetencija neophodnih za rad sa ljudima, sve četiri visokoškolske vojne ustanove imaju razvijene predmete ove oblasti.

Tako je ustanovljeno da Univerzitet odbrane Republike Češke ima nešto razvijenije programe predmeta koji su usmereni ka razvoju interpersonalnih kompetencija neophodnih za rad sa ljudima uopšte. Komparativna analiza ukazala je na činjenicu da su studijski programi Univerziteta odbrane u Beogradu na svim nivoima studija zasićeniji predmetima koji proučavaju probleme neophodnih za rad sa ljudima u vojnoj sredini, i da samim tim studije ovog Univerziteta posebnu pažnju poklanjaju razvijanju kompetencija neophodnih za rad sa ljudima, odnosno neophodnih profilu kadrova u vojsci, dok Univerzitet odbrane Republike Češke neguje koncepciju usmerenu ka formiranju proučavanih kompetencija, ne vezujući se samo za oblast vojne sredine. Pri tome, svoje programe usmeravaju ka užoj oblasti proučavanih naučnih područja, pre svega ka problemu komunikacija. Komparativne analize ukazuju nam i na činjenicu da se u okviru sve četiri visokoškolske ustanove, posebna pažnja poklanja i razvoju sistemskih proučavanih kompetencija. Takođe, komparativna analiza pokazuje da Univerzitet odbrane Republike Češke ima razvijenije predmete iz oblasti ekonomije, odnosno posebnu pažnju poklanja razvijanju sistemskih kompetencija oficira neophodnih za finansijsko upravljanje sistemom odbrane.

U svakom slučaju vojni poslovi su veoma diversifikovani pa je za njihovo obavljanje potrebno posedovanje različitih kompetencija. I pored toga postoje neke zajedničke karakteristike različitih vojnih poslova, koje obuhvataju brigu o ljudima, i to kako o čoveku kao o poje- 
dincu, tako i o čoveku kao delu celokupne društvene zajednice. Upravo tu leži snaga društvenih nauka, koja omogućava analiziranje i kritičko promišljanje pojava globalnog društva, neophodnog za shvatanje društvene suštine rata i mira i vojske kao društvene institucije.

\section{Literatura}

[1] Alibabić, Š. (2002), Teorija organizacije obrazovanja odraslih, IPA, Beograd.

[2] Alibabić, Š., (2004), Menadžment u obrazovanju, Zbornik FCO, Beograd.

[3] Alibabić, Š., (2006), Menadžment promena u obrazovanju, Evropske dimenzije reforme sistema obrazovanja i vaspitanja, Odsek za pedagogiju Filozofskog fakulteta u Novom Sadu, Novi Sad.

[4] Jeftić, Z., Vuruna, M. (2009), Reforma vojnog obrazovanja u Republici Srbiji - mogućnosti, izazovi i pravci razvoja, Vojno delo, br. 1, Beograd.

[5] Kasagić Lj., Kostić P., (1992), Psihologija za vojnog starešinu, Vojna akademija, Beograd.

[6] Kasagić Lj., Pajević D., (2001), Vojna psihologija, Vojno-izdavački zavod, Beograd.

[7] Kostić, P., (1984), Poželjne osobine ličnosti oficira nekih savremenih armija, Zbornik radova Vojne akademije Kopnene vojske.

[8] Marček, J., (2003), Profil oficira i interpersonalni odnosi, Generalštab Vojske Srbije i Crne gore, Uprava za školstvo i obuku, Vojna akademija, Beograd.

[9] Marček, J., Savić, A., Danić, N., Suša, B., (2006), Profil oficira rodova i službi vojske Srbije, Vojno izdavački zavod, Beograd.

[10] Marček, J., Jeremić R., (2009), Reforma visokog vojnog školstva u Republici Srbiji - misije Vojske Srbije i Bolonjski proces, Vojno delo, br. 4/2009, Beograd.

[11] Marček, J., i sar. (2011), Reforma sistema visokog vojnog obrazovanja Republike Srbije, Vojna akademija, Sektor za ljudske resurse, Ministarstvo odbrane, Beograd.

[12] Marček, J., Kilibarda, Z., (2011), Obrazovne potrebe oficira Vojske Srbije za menadžment u sistemu odbrane, Zbornik radova sa naučno-stručnog skupa sa međunarodnim učešćem „Potrebna znanja oficira Vojske Srbije 2010-2020", Ministarstvo odbrane, Sektor za ljudske resurse, Vojna akademija, Sektor za politiku odbrane, Institut za strategijska istraživanja, Beograd.

[13] Marček, J., Životić Vanović M., Dikić G., (2014), Savremeni tokovi reforme visokog obrazovanja (monografija), Odbrana, Beograd.

[14] Marček, J., (2017), Reforma visokog vojnog obrazovanja u funkciji integralne bezbednosti Republike Srbije, u: Grupa autora, Integralna bezbednost Republike Srbije (praktičan aspekt), (tematska monografija), Beograd: Fakultet za poslovne studije i pravo, Fakultet za informacione tehnologije i inžinjerstvo, Univerzitet „Union - Nikola Tesla“, Beograd.

[15] Milošević-Stolić, J., (2007), Obrazovne potrebe oficira na početnim dužnostima u VSCG (magistarski rad), Beograd: Filozofski fakultet.

[16] Milošević Stolić, J., Alibabić, Š., (2014), Obrazovna podrška menadžerskim aktivnostima vojnih starešina, Andragoške studije, Beograd.

[17] Flivbjerg B., (2012), Šta mogu društvene nauke - razlozi neuspeha i strategije za budućnost, Službeni glasnik, Beograd.

[18] Univerzitet odbrane Češke Republike, (2019) www.unob.cz [Pristupljeno 10.01.2019]

[19] Univerzitet odbrane u Beogradu, (2019) www.uo.mod.gov.rs [Pristupljeno 10.01.2019]

[20] Vojni univerzitet u Zagrebu (2019) www.vojni.unizg.hr [Pristupljeno 11.01.2019]

[21] Univerzitet „Goce Delčev“ Štip, (2019) Voena akademija, General.

[22] Mihailo Apostolski “ - Skopje, 2012. www.ma.edu.mk [Pristupljeno 15.01.2019] 